\title{
Correction to: Emplaced social vulnerability to technological disasters: Southeast Louisiana and the BP Deepwater Horizon oil spill
}

\author{
Michael R. Cope ${ }^{1} \cdot$ Tim Slack $^{2}$
}

Published online: 1 June 2018

(C) Springer Science+Business Media, LLC, part of Springer Nature 2018

Correction to: Population and Environment

DOI https://doi.org/10.1007/s11111-016-0257-8

The original version of this article inadvertently did not include the following acknowledgement of funding:

Funding information This research was made possible by a grant from The Gulf of Mexico Research Initiative (GoMRI). Data are publicly available through the Gulf of Mexico Research Initiative Information \& Data Cooperative (GRIIDC) at https://data.gulfresearchinitiative.org (doi: https://doi. org/10.7266/N7T72FDS, https://doi.org/10.7266/N7PG1PP2, https://doi.org/10.7266/N7JQ0XZB, https://doi.org/10.7266/N7DZ068V).

The online version of the original article can be found at https://doi.org/10.1007/s11111-016-0257-8

Michael R. Cope

michaelrcope@byu.edu

1 Department of Sociology, Brigham Young University, 2008 JFSB, Provo, UT 84602, USA

2 Louisiana State University, Baton Rouge, LA, USA 